Authorities, interested in actuarial - financial mathematics.

Topics:

- Modelling Catastrophic Risks in Insurance and Finance (Chair: Holger Drees)

- Risk Measures in Non-Life Insurance and Portfolio Management (Chair: Zinovyi Landsman)

- Risk and Stochastic Control (Chair: Soeren Asmussen)

- Financial Risk Management (Chair: Thaleia Zariphopoulou)

- Modelling Dependence in Multivariate Risk (Chair: Gena Samorodnitsky)

- Decision Making in Life, Health and Pension Insurance (Chair: Mogens Steffensen)

A short course will be given before the conference (May 31-June 2) under the title:

- Financial Modelling with Levy Processes, by Rama Cont - Columbia University, USA

Invited Speakers:

- Philippe Soulier - University Paris X, France

- Paul Embrecths - ETH Zurich, Switzerland

- Peter Glynn - Stanford University, USA

- Xunyu Zhou - Oxford University, United Kingdom

- Henrik Hult - KTH (Royal Institute of Technology), Sweden

- Erhan Bayraktar - University of Michigan, USA

- Seva Shneer-Eurnadom, The Netherlands

\title{
Scientific Committee:
}

$\begin{array}{llll}\text { Albrecher Hansjoerg } & \text { Gerber Hans } & \text { Mikosch Thomas } & \text { Samorodnitsky Gena } \\ \text { Asmussen Soeren } & \text { Goovaerts Marc } & \text { Morettin Pedro } & \text { Steffensen Mogens } \\ \text { Cheliotis Dimitris } & \text { Konstantinides Dimitrios } & \text { Ng Kai Wang } & \text { Teugels Jef } \\ \text { Drees Holger } & \text { Makov Udi } & \text { Papaioanou Takis (Chair) } & \text { Tang Qihe } \\ \text { Foss Serguei } & \text { Marceau Etienne } & & \text { Zariphopoulou Thaleia }\end{array}$




\section{CAMBRIDGE JDUNALS}

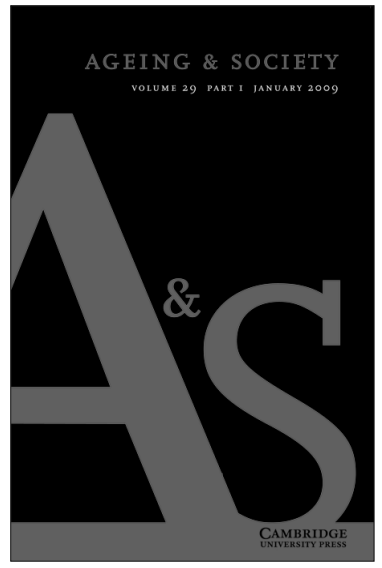

\section{Ageing \& Society}

is available online at:

http:/ljournals.cambridge.org/aso

To subscribe contact Customer Services

in Cambridge:

Phone +44 (0)1223 326070

Fax $+44(0) 1223325150$

Email journals@cambridge.org

in New York:

Phone (845) 3537500

Fax (845) 3534141

Email

subscriptions_newyork@cambridge.org

\section{AGEING \& SOCIETY}

The Journal of The Centre for Policy on Ageing and The British Society of Gerontology

\section{Editor}

Tony Warnes, University of Sheffield, UK

Ageing \& Society is an interdisciplinary and international journal devoted to publishing papers which further the understanding of human ageing in the wider social and cultural context. Ageing \& Society features an extensive book review section and a regular updating on specified research areas.

\section{Price information is available at: http://journals.cambridge.org/aso}

\section{Free email alerts}

Keep up-to-date with new material - sign up at http://journals.cambridge.org/alerts

For free online content visit: http://journals.cambridge.org/aso 


\section{CAMBRIDGE}

\section{JOURNALS}

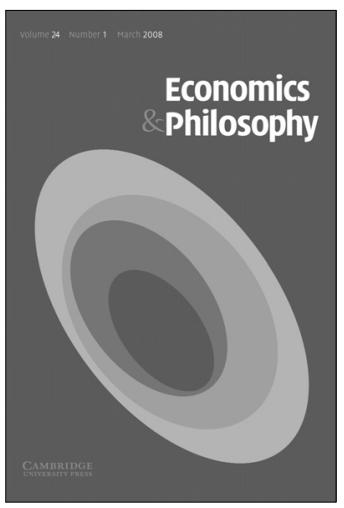

\section{Economics and Philosophy}

is available online at

http://journals.cambridge.org/eap

To subscribe contact

Customer Services

in Cambridge:

Phone +44 (0)1223 326070

Fax $+44(0) 1223325150$

Email journals@cambridge.org

in New York:

Phone (845) 3537500

Fax (845) 3534141

Email

subscriptions_newyork@cambridge.org

\section{Economics \& Philosophy}

\section{Editors}

Giacomo Bonanno, University of California, Davis, USA Martin van Hees, University of Groningen, Netherlands Christian List, London School of Economics, UK Bertil Tungodden, Norwegian School of Economics and Business Administration, Norway

Economics and Philosophy examines the foundations of economics and its cognate disciplines from a philosophical perspective. Topics include the methodology and epistemology of economics, the foundations of decision theory and game theory, the nature of rational choice and the use of economic techniques in ethical theory.

\section{Price information is available at http://journals.cambridge.org/eap}

\section{Free email alerts}

Keep up-to-date with new material - sign up at http://journals.cambridge.org/alerts 


\section{CAMBRIDGE}

\section{JOURNALS}

Fnvironment and

Development

Economics

Volume 13 Partl

February 2008

$\operatorname{ansi}$

\section{Environment and \\ Development \\ Economics}

Published in association with the Beijer Institute of Ecological Economics, Royal Swedish Academy of Sciences

\section{Editor}

Environment and Development Economics

Anastasios Xepapadeas, University of Crete, Greece

is available online at:

http:/ljournals.cambridge.org/ede

To subscribe contact

Customer Services

in Cambridge:

Phone +44 (0)1223 326070

Fax +44 (0)1223 325150

Email journals@cambridge.org

\section{in New York:}

Phone (845) 3537500

Fax (845) 3534141

Email

subscriptions_newyork@cambridge.org

\section{Environment and Development Economics is firmly} positioned at the intersection of economics, environment and development, publishing original papers addressed to the research and policy communities, and is designed to be accessible to a broad readership. The Editor and Associate Editors are supported by distinguished panels of advisors from around the world, who together ensure that the journal is a major forum for key research conducted in low-income countries as well as elsewhere, and for the work of younger scholars. The journal is divided into two main sections, Theory and Applications and Policy Options.

\section{Price information is available at: http://journals.cambridge.org/ede}

\section{Free email alerts}

Keep up-to-date with new material - sign up at http://journals.cambridge.org/alerts

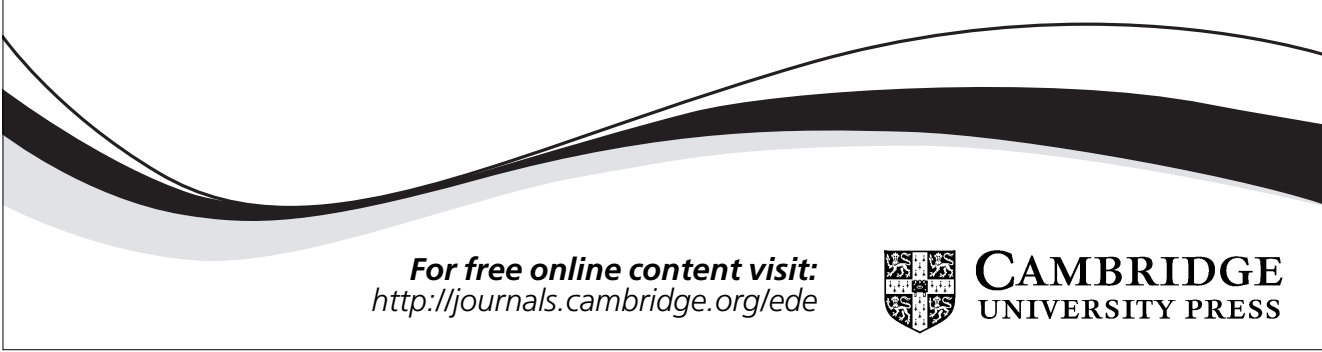




\section{CAMBRIDGE}

\section{JOURNALS}

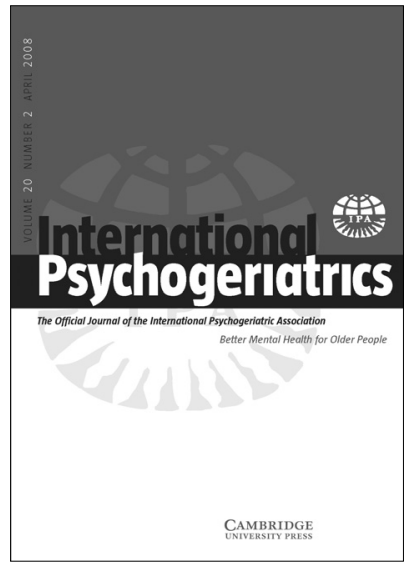

International Psychogeriatrics

is available online at

journals.cambridge.org/ipg

To subscribe contact

Customer Services

in Cambridge:

Phone $+44(0) 1223326070$

Fax $+44(0) 1223325150$

Email journals@cambridge.org

in New York:

Phone (845) 3537500

Fax (845) 3534141

Email

subscriptions_newyork@cambridge.org
International Psychogeriatrics

Published for the Interntaional Psychogeriatric Association.

\section{Editor-in-Chief}

David Ames, University of Melbourne, Australia

A well-respected, multidisciplinary journal, International Psychogeriatrics offers high quality original research papers in the field of psychogeriatrics. The journal aims to be the leading peer reviewed journal dealing with the mental health of older people throughout the world in all its aspects.

Price information is available at journals.cambridge.org/ipg

\section{Free email alerts}

Keep up-to-date with new material sign up at journals.cambridge.org/register 


\section{CAMBRIDGE}

\section{JOURNALS}

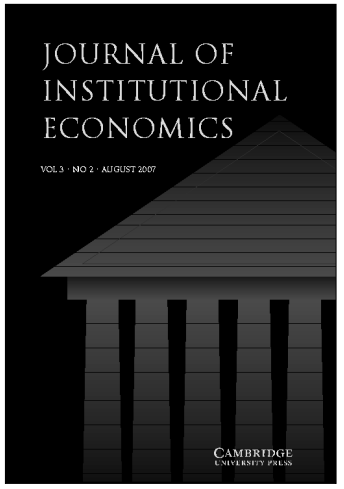

\section{Journal of Institutional Economics} is available online at: journals.cambridge.org/joi

To subscribe contact Customer Services

in Cambridge:

Phone $+44(0) 1223326070$

Fax $+44(0) 1223325150$

Email journals@cambridge.org

\section{in New York:}

Phone (845) 3537500

Fax (845) 3534141

Email

subscriptions_newyork@cambridge.org

\section{Journal of} Institutional Economics

\section{Editor-in-Chief}

Geoffrey M. Hodgson, University of Hertfordshire, UK

Institutions are the stuff of social and economic life. The importance of understanding the role of institutions in economic growth is now widely appreciated. The Journal of Institutional Economics is devoted to the study of the nature, role and evolution of institutions in the economy, including firms, states, markets, money, households and other vital institutions and organizations. It welcomes contributions by all schools of thought that can contribute to our understanding of the features, development and functions of real world economic institutions and organizations.

Price information is available at: journals.cambridge.org/joi

\section{Free email alerts} Keep up-to-date with new material sign up at www.journals.cambridge.org/register

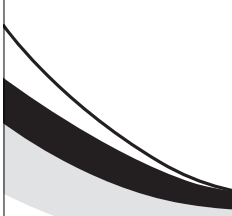

For a free online sample visit: journals.cambridge.org/joi 


\section{Instructions for Contributors}

\section{Contributions}

The journal publishes original academic research papers on the economics and finance of pensions, retirement income and ageing. The Journal also publishes "Issues and Policy" articles which review the state of knowledge or the debate in particular areas. Papers from actuarial science, mathematics, statistics and other disciplines are welcome as long as there is a clear economics or finance context. Examples of subjects the journal will cover include: pensions and labour markets, the macro and micro economics of pensions, pension fund management, regulation of pensions, valuation of pension liabilities, corporate governance, political economy issues, financial planning for retirement and marketing of private pensions.

\section{Manuscripts}

All manuscripts must be submitted online via the website:

\section{http://mc.manuscriptcentral.com/jpef}

Detailed instructions for submitting your manuscript online can be found the submission website by clicking on the 'Instructions and Forms' link in the top right of the screen; and then clicking on the 'Author Submission Instructions' icon on the following page.

The Editor will acknowledge receipt of the manuscript, provide it with a manuscript reference number and assign it to reviewers. The reference number of the manuscript should be quoted in all correspondence with PEF Office and Publisher.

Manuscripts should begin with an abstract of not more than 300 words and ordinarily should not exceed 35 pages in length. Manuscripts will be reviewed by the editors and by referees chosen by the editors.

Manuscripts are accepted for review on the understanding that the same work has not been and will not be published nor is presently submitted elsewhere. While under editorial review, it is the responsibility of the authors to keep the Editors informed about submissions, publication plans, and actual publication of related research or abstracts thereof in other outlets, including letters, journals, review publications, journals in other disciplines, conference proceedings, and published dissertations. It is further understood that all persons listed as authors have given their approval for the submission of the paper and that any person cited as a source of personal communication has approved such citation; written authorization may be required at the Editor's discretion. Authors are responsible for obtaining written permission to publish material for which they do not own the copyright. Articles and other material published in Journal of Pension Economics and Finance represent the opinions of the authors and should not be construed to reflect the opinions of the Editors or their employers or the Publisher.

\section{Electronic submission of final manuscripts and illustrations}

A LaTeX class file is available. The PEF class file and instructions are available by anonymous FTP from ftp://ftp.cup.cam.ac.uk/pub/texarchive/journals/latex/pef-cls/ LaTeX manuscripts should be accompanied by a pdf of the entire article so it can be printed out. The journal does not print in colour, so all figutes should be black and white for reproduction.

\section{References}

The Harvard system of references should be used. Citations are by author's surname and year of publication, and may stand either as a noun phrase (e.g., "Diamond (1965)") or as a parenthetical note (e.g., "(Diamond 1965)"). List references at the end of the text in alphabetical order. A typical entry is: Diamond, P. (1965) National Debt in a Neoclassical Debt Model, Journal of Political Economy, 55 (December): 1126-1150.

\section{Offprints}

Authors will receive a pdf of their article upon publication, and 25 offprints of each article will be supplied free to each first named author. Extra offprints may be purchased from the publisher if ordered at proof stage.

This journal issue has been printed on FSC-certified paper and cover board. FSC is an independent, non-governmental, not-for-profit organization established to promote the responsible management of the world's forests. Please see www.fsc.org for information. 


\section{VOLUME 8 \\ Journal of \\ Pension Economics \\ \& Finance}

\section{ARTICLES}

259 The decline of defined benefit plans and job tenure

Allison Schrager

291 The impact of private participation and countervailing information on disability costs: evidence from Chile

Estelle James, Alejandra Cox Edwards and Augusto Iglesias

321 Welfare analysis of conditional indexation schemes from a two-reference-point perspective

Renxiang Dai and J. M. Schumacher

351 What discount rate should be used to value a cash-flow linked to final salary? Zaki Khorasanee

361 Lifecycle derivatives and retirement income assurance using long-term debt Roger J. Bowden 